\title{
Inheritance of self-compatibility in almond
}

\author{
F. DICENTA \& J. E. GARCÍA \\ CEBAS (CS/C), Murcia, Spain
}

\begin{abstract}
The incidence of self-compatibility in 742 almond trees, resulting from 25 inter-cultivar crossings in which at least one of the parents is self-compatible (Genco and Tuono), was determined by means of microscopic observation of the pollen tube growth in the pistil. The data obtained are consistent with the assumption that self-incompatibility in the genus Prunus is controlled by a single, multiallelic gene whose expression in the pollen is gametophytic. The 100 per cent occurrence of selfcompatible specimens in the cross where the Ferragnès cultivar is the female parent is due to the existence of an allele shared with the self-compatible cultivars used. The high number of progeny examined and the method used to ascertain the self-compatibility make the results very reliable, as opposed to other less precise methodologies or tests with few seedlings.
\end{abstract}

Keywords: fluorescence microscopy, fruit breeding, intraspecific crossings, Prunus dulcis Miller, self-pollination.

\section{Introduction}

Most cultivars of almond are self-incompatible. Its cultivation, therefore, requires the planting of at least two cross-compatible cultivars with coincident flowering time and the setting up of beehives to secure enough pollinating agents. Moreover, favourable environmental conditions must be obtained for bees to work effectively. The separate collection of the different cultivars is also necessary, either because of the different morphology of their fruits or their different maturing times.

Jointly these factors have a large impact on the profitability of the crop, hence the breeding of selfcompatible cultivars is a priority in almond breeding schemes.

Only a limited number of the numerous almond cultivars grown worldwide are self-compatible. The majority come from the Italian region of Apulia (Godini, 1979; Reina et al., 1986). Prominent among these are Tuono and Genco (Stazione Agraria Sperimentale di Bari, 1951, 1957), Filippo Ceo (Grasselly \& Oliver, 1976), Mazzetto - synonymous for Tuono - (Jaouani, 1973), Exinograd (Cyprus Agricultural Research Institute, 1973), Falsa Barese, Ferrante and Palatina (Godini, 1977).

Correspondence: Dr F. Dicenta, Station de Recherches Fruitières Méditerranéennes, Domaine de Saint-Paul, BP 91, 84143 Montfavet, France.
As these cultivars were shown to be capable of transmitting their self-compatibility to their offspring (Socías i Company \& Felipe, 1977), using them has proved to be the most effective method for obtaining new self-compatible cultivars.

A knowledge of the inheritance of self-compatibility is an essential step in the attainment of such an objective. The incompatibility system in the genus Prunus appears to be controlled by a single, multi-allelic gene whose expression in the pollen is gametophytic (Crane \& Brown, 1937; Crane \& Lawrence, 1947; Lewis \& Crowel, 1954).

This system seems to occur in the almond species, although there are few works to this effect (Grasselly, 1985; Jraidi \& Nefzi, 1988; Socías i Company, 1989). In general, the plant material studied has not been very abundant and occasionally the interpretation of the results has not been accurate.

\section{Plant material and methodology}

The presence or absence of self-compatibility has been ascertained in 742 seedlings belonging to 25 families produced by manual pollination, in which one or both parents are the self-compatible varieties Genco or Tuono (Table 1).

The self-compatibility of the progenies has been ascertained by means of microscopic observation of the pollen tube growth in the pistil, according to the following procedure. 
Table 1 Number and percentage (\%) of self-compatible (SC) and self-incompatible (SiC) seedlings by families

\begin{tabular}{lrrrrrll}
\hline Crosses & Total & \multicolumn{1}{l}{ SC } & $\%$ & SiC & \multicolumn{1}{l}{$\chi^{2}$} & Significance \\
\hline Peraleja $\times$ Genco & 20 & 9 & 45.0 & 11 & 55.0 & 0.200 & 0.654 \\
Garrigues $\times$ Genco & 37 & 18 & 48.6 & 19 & 51.4 & 0.027 & 0.869 \\
Atocha $\times$ Genco & 59 & 27 & 45.8 & 32 & 54.2 & 0.424 & 0.515 \\
Ramillete $\times$ Genco & 48 & 13 & 27.1 & 35 & 72.9 & 10.083 & 0.001 \\
Del Cid $\times$ Genco & 47 & 11 & 23.4 & 36 & 76.6 & 13.294 & 0.000 \\
Genco $\times$ Genco & 2 & 2 & 100.0 & 0 & 0.0 & - & - \\
Ferragnès $\times$ Genco & 44 & 41 & 93.2 & 3 & 6.8 & - & - \\
Mono $\times$ Genco & 14 & 6 & 42.9 & 8 & 57.1 & 0.286 & 0.593 \\
Titan $\times$ Genco & 2 & 1 & 50.0 & 1 & 50.0 & - & - \\
Wawona $\times$ Genco & 1 & 0 & 0.0 & 1 & 100.0 & - & - \\
Genco $\times$ Garrigues & 17 & 8 & 47.1 & 9 & 52.9 & 0.059 & 1.808 \\
Genco $\times$ Ramillete & 26 & 10 & 38.5 & 16 & 61.5 & 1.384 & 0.239 \\
Genco $\times$ Ferragnès & 25 & 14 & 56.0 & 11 & 44.0 & 0.360 & 0.548 \\
Genco $\times$ Mono & 21 & 13 & 61.9 & 8 & 38.1 & 1.190 & 0.275 \\
Genco $\times$ Tuono & 20 & 19 & 95.0 & 1 & 5.0 & - & - \\
Tuono $\times$ Genco & 51 & 47 & 92.2 & 4 & 7.8 & - & - \\
Peraleja $\times$ Tuono & 54 & 32 & 59.3 & 22 & 40.7 & 1.851 & 0.173 \\
Garrigues $\times$ Tuono & 43 & 15 & 34.9 & 28 & 65.1 & 3.930 & 0.047 \\
Atocha $\times$ Tuono & 22 & 14 & 63.6 & 8 & 36.4 & 1.636 & 0.200 \\
Ramillete $\times$ Tuono & 53 & 32 & 60.4 & 21 & 39.6 & 2.283 & 0.131 \\
Del Cid $\times$ Tuono & 18 & 7 & 38.9 & 11 & 61.1 & 0.889 & 0.346 \\
Tuono $\times$ Tuono & 1 & 1 & 100.0 & 0 & 0.0 & - & - \\
Ferragnès $\times$ Tuono & 50 & 50 & 100.0 & 0 & 0.0 & - & - \\
Mono $\times$ Tuono & 14 & 11 & 78.6 & 3 & 21.4 & 4.571 & 0.032 \\
Tuono $\times$ Ferragnès & 53 & 36 & 67.9 & 17 & 32.1 & 6.811 & 0.009 \\
Total & 742 & 437 & 58.9 & 305 & 41.1 & & \\
\hline Cis & & & & & & & \\
\hline
\end{tabular}

Chi-squared and signification level.

From each seedling 10 buds were collected in state D (Felipe, 1977); they were emasculated in the laboratory, sparing only the pistil with a part of the calyx and the floral peduncle. These were carefully placed in trays with semi-stiff plastic mesh to hold the emasculated buds, thus allowing contact between the peduncle and the water on the tray. The pollen of the 10 emasculated buds were collected in small paper wells, to be used in subsequent self-pollination.

The trays containing the pistils and the wells carrying the pollen were placed in an atmosphere-controlled room, with a photoperiod of $12 \mathrm{~h}$, at $22 \pm 1^{\circ} \mathrm{C}$ and a high relative humidity $(70-80$ per cent) to prevent the stigmas from drying up. After $24 \mathrm{~h}$, the 10 pistils of each sample were self-pollinated using a small brush to apply the pollen.

Seventy-two hours after pollination the pistils were placed in small glass bottles with $5 \mathrm{ml}$ of FAA, a fixing solution, made up of 5 per cent of formaldehyde (at 40 per cent), 5 per cent glacial acetic acid and alcohol 90 per cent (at 70 per cent $v / v)$. At that point the peduncle and the remains of the calyx were eliminated. The samples were thereafter kept in a refrigerator at $4^{\circ} \mathrm{C}$ pending observation.

Prior to microscopic examination, the pistils were washed and kept for $30 \mathrm{~min}$ in a sterilizer at $1 \mathrm{~kg} \mathrm{~cm}^{-2}$ in a solution of sodium sulphite at 5 per cent, which softens the tissue and enhances staining. The stain used was aniline blue at 0.1 per cent in $0.1 \mathrm{~N}$ potassium phosphate. Finally, the pistils were carefully stripped of their pubescence before being placed on slides. After crushing them, they were examined by fluorescence microscopy (Linskens \& Esser, 1957; Martin, 1959).

Usually, five pistils per sample were examined and the level of penetration of the pollen tubes in each pistil ascertained. When the five pistils did not show homogeneous behaviour, the five remaining pistils were also examined. In general, the presence of at least two pistils in which the pollen tubes clearly reached the ovary was decisive in assigning self-compatibility to that sample.

The data from each family were analysed by goodness-of-fit $\chi^{2}$. 


\section{Results and discussion}

Table 1 shows the number and percentage of selfcompatible (SC) and self-incompatible ( $\mathrm{SiC}$ ) seedlings for each family.

Note that the size of the sample analysed ranges from 14 to 59, except the (Wawona and Titan) $\times$ Genco progeny and those resulting from self-pollination. In the latter, although we started with a large number of seeds (García et al., 1985), very few progeny were obtained, due presumably to the severe inbreeding also observed by other authors (Grasselly et al., 1981; Grasselly \& Oliver, 1988).

Note that in only six combinations of the 25 shown in Table 1 did all, or practically all, their progeny turn out to be self-compatible. These are the four combinations in which both parents are self-compatible and the two in which Ferragnès was used as female parent.

The results obtained from the progenies of the 19 remaining crosses gave either approximately 50 per cent self-compatible trees, such as (Peraleja, Garrigues and Atocha) $\times$ Genco, or showed marked deviations, either below or above this value. In the cases of Ramillete and Del Cid $\times$ Genco, however, flower sterility, pollinations were made outside the pollinating period or other uncontrolled factors, either genetic or atmospheric, may have contributed to the significance deviations from expected.

We can distinguish two groups according to their differential behaviour, as shown in Table 2. One can see that Group I includes the crosses between SC and $\mathrm{SiC}$ cultivars (except Ferragnès when it acted as female parent). These crosses produced approximately 50 per cent SC offspring. Note that Tuono behaved better than Genco as far as production of self-compatible offspring is concerned.
Group II shows the results obtained from crosses between SC parents, selfs and Ferragnès crosses (as female parent) with SC cultivars. The progenies belonging to this group display a percentage of SC trees which is very close to 100 per cent $(95.2$ per cent).

Assuming that the inheritance of self-compatibility in almond is the same as that in other Prunus species, we summarize in Fig. 1 the theoretical possibilities of crossing among $\mathrm{SC}$ and $\mathrm{SiC}$ cultivars, considering two assumptions:with and without a shared allele.

The crosses belonging to Group I, assuming 50 per cent SC:50 per cent $\mathrm{SiC}$, could be assigned to hypothetical cases A, B or E in Fig. 1. As there is no reason to believe that the $\mathrm{SiC}$ varieties are related to either Genco or Tuono, it is unlikely that they share an allele with either of the latter, thus the hypothetical case E can be discarded, and they must correspond to case A where the SC cultivar was the female and case B where it was the male; both yielding an identical result.

As a consequence, our $\mathrm{SiC}$ parents (except Ferragnès) do not appear to share any alleles with either Genco or Tuono and, given the fact that they are intercompatible (García, 1978; García et al., 1985; Egea et al., 1988), it is expected that they will, at least, differ in one of their $\mathrm{S}$ alleles.

The crosses in Group II could conform to hypothetical cases $F, G$ or $H$ because they are the only cases which produce 100 per cent self-compatible seedlings in the offspring. In cases of self-pollination $\left(\mathrm{SC}_{1}=\mathrm{SC}_{2}\right)$ and crosses between $\mathrm{SC}$ cultivars, the only theoretical possibilities are $\mathrm{G}$ or $\mathrm{H}$, both of which give an identical result, which suggests that our two self-compatible parents have the same genotype for self-compatibility. The Ferragnès $\times$ SCs case, assigned to Group II, has to match necessarily hypothetical case $F$, this being the

Table 2 Number and percentage of self-compatible (SC) and self-incompatible (SiC) seedlings by groups

\begin{tabular}{lrrrrrlll}
\hline & NF & Total & \multicolumn{1}{l}{ SC } & $\%$ & SiC & $\%$ & $\chi^{2}$ & Significance \\
\hline Group I & & & & & & & & \\
SiC $\times$ Genco & 8 & 228 & 85 & 37.3 & 143 & 62.7 & 14.754 & 0.000 \\
$\mathrm{SiC} \times$ Tuono & 6 & 204 & 111 & 54.4 & 93 & 45.6 & 1.588 & 0.207 \\
Genco $\times$ SiC & 4 & 89 & 45 & 50.6 & 44 & 49.4 & 0.011 & 0.915 \\
Tuono $\times$ SiC & 1 & 53 & 36 & 67.9 & 17 & 32.1 & 6.811 & 0.009 \\
Total Group I & 19 & 574 & 277 & 48.3 & 297 & 51.7 & 0.696 & 0.403 \\
Group II & & & & & & & & \\
SC $\times$ SC & 2 & 71 & 66 & 93.0 & 5 & 7.0 & - & - \\
Self-pollination & 2 & 3 & 3 & 100.0 & 0 & 0.0 & - & - \\
Ferragnès $\times$ SC & 2 & 94 & 91 & 96.8 & 3 & 3.2 & - & - \\
Total Group II & 6 & 168 & 160 & 95.2 & 8 & 4.3 & - & - \\
\hline
\end{tabular}

$\mathrm{NF}=$ Number of families. Chi-squared and signification level. 
(a)

\begin{tabular}{|c|c|c|c|c|c|c|c|}
\hline$A$ & SC & $x$ & bic & \multicolumn{2}{|r|}{$\mathrm{SiC}$} & \multicolumn{2}{|r|}{ SC } \\
\hline \multicolumn{2}{|c|}{$S_{f} S_{1}$} & S & $S_{3}$ & \multicolumn{2}{|c|}{$\mathrm{S}_{2} \mathrm{~S}_{3}$} & \multicolumn{2}{|c|}{$s_{f} s_{1}$} \\
\hline$S_{f} S_{2}$ & $\mathrm{~S}_{4} \mathrm{~S}_{3}$ & $S_{1} S_{2}$ & $\mathrm{~S}_{1} \mathrm{~S}_{3}$ & $\mathrm{~S}_{2} \mathrm{~S}_{f}$ & $S_{3} S_{f}$ & $S_{1} S_{2}$ & $\mathrm{~S}_{1} \mathrm{~S}_{3}$ \\
\hline \multicolumn{2}{|c|}{$50 \% \mathrm{SC}$} & \multicolumn{2}{|c|}{$50 \% \mathrm{SiC}$} & \multicolumn{2}{|c|}{$50 \% \mathrm{SC}$} & \multicolumn{2}{|c|}{$50 \% \mathrm{SiC}$} \\
\hline \multicolumn{2}{|c|}{$\mathrm{SC}_{1}$} & $x$ & $\mathrm{C}_{2}$ & \multicolumn{2}{|c|}{$\mathrm{SC}_{2}$} & \multicolumn{2}{|c|}{$\mathrm{SC}_{1}$} \\
\hline \multicolumn{2}{|c|}{$S_{f} S_{1}$} & \multicolumn{2}{|c|}{$S_{f} S_{2}$} & \multicolumn{2}{|c|}{$S_{4} S_{2}$} & \multicolumn{2}{|c|}{$S_{f} S_{i}$} \\
\hline$S_{f} S_{f}$ & $S_{1} S_{f}$ & $S_{f} S_{2}$ & $\mathrm{~S}_{1} \mathrm{~S}_{2}$ & $\mathrm{~S}_{f} \mathrm{~S}_{f}$ & $S_{2} S_{f}$ & $S_{f} S_{i}$ & $\mathrm{~S}_{1} \mathrm{~S}_{2}$ \\
\hline \multicolumn{2}{|c|}{$75 \%$ SC } & & $5 \% \mathrm{SiC}$ & \multicolumn{2}{|c|}{$75 \%$ SC } & & $5 \% \mathrm{SiC}$ \\
\hline
\end{tabular}

(b)

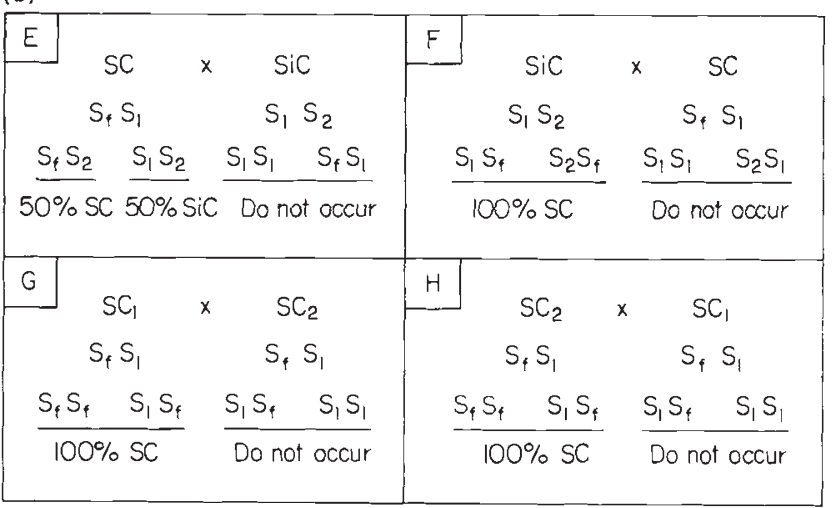

Fig. 1 Theoretical possibilities of crosses between $\mathrm{SC} \times \mathrm{SiC}$ and $\mathrm{SC}_{1} \times \mathrm{SC}_{2}$ and expected genetic frequency in a monogenic and gametophytic scheme of self-incompatibility. $S_{\mathrm{f}}=$ self-compatible allele. $S_{i}=$ self-incompatible. (a) Without shared $\mathrm{S}_{\mathrm{i}}$, (b) with shared $\mathrm{S}_{\mathrm{i}}$.

only possibility for 100 per cent of the offspring to be $\mathrm{SC}$ with a SiC parent taking part. This is backed up by the possibility of Ferragnès sharing a self-incompatible allele with Genco and Tuono, transmitted from its Cristomorto parents (Ferragnès $=$ Cristomorto $\times \mathrm{Ai}$ ), which belongs to the same population as Genco and Tuono. Moreover, if we observe their reciprocal crosses (Genco and Tuono) $\times$ Ferragnès, included in Group I, we can observe that these crosses conform to hypothetical case $\mathrm{E}$, thus Ferragnès should have the same $\mathrm{S}_{1}$ as Genco and Tuono.

The Chi-squared test (Table 1) discloses that the hypothesis 50 per cent $\mathrm{SC}$ : 50 per cent $\mathrm{SiC}$, if we cross a SC cultivar with a SiC one (always barrring Ferragnès $\times \mathrm{SC}$ ), must be accepted in practically all the crosses. Only in (Ramillete and Del Cid) $\times$ Genco did the results depart significantly from those expected and in Tuono $\times$ Ferragnès they hardly conformed at all. In the joint study of this group of crosses (Group I in
Table 3 New planned crosses which will supply 100 per cent of the self-compatible issue. (See hypothetical cases in Fig. 1.)

$\begin{array}{cc}\text { Cases A and B } & \text { Case E } \\ \text { Seedling SiC } \times \text { Parent SC } & \text { Seedling SiC } \times \text { Parent SC } \\ \text { Parent SiC } \times \text { Seedling SC } & \text { Parent SiC } \times \text { Seedling SC } \\ & \text { Seedling SiC } \times \text { Seedling SC } \\ \text { Case F } & \text { Cases G and H } \\ \text { Parent SiC } \times \text { Seedling SC } & \text { Parent SC } \times \text { Seedling SC } \\ & \text { Seedling SC } \times \text { Seedling SC } \\ & \text { Ferragnès } \times \text { Seedling SC }\end{array}$

Table 2) we clearly perceive that our results do not significantly disagree with the established hypothesis.

Taken as a whole, these data suggest that selfcompatibility in this material is determined by an allele of the self-incompatibility gene which is dominant over all the other alleles at this locus, a conclusion which agrees with those of other authors (Socías i Company, 1984; Grasselly et al., 1985; Socías i Company \& Felipe, 1988).

Only in the crosses in which Ferragnès was the female parent were the genotypic frequencies completely unexpected. This anomalous behaviour of Ferragnès has been studied by Grasselly et al., (1981), and by Socías i Company \& Felipe (1988). Grasselly (1985) accounted for this phenomenon by arguing for the presence of a shared self-incompatibility allele, offering as evidence the possible kinship of Ferragnès with Genco and Tuono, although his theoretical development does not explain satisfactorily the results he arrived at. Socías i Company \& Felipe (1988), on the other hand, relate this high rate of SC seedlings to a decrease in $\mathrm{SiC}$ genotypes due to depression phenomena caused by inbreeding, or due to the presence of a lethal gene linked in repulsion to self-compatibility. The results we have arrived at in this work do not tally with this latter hypothesis and reaffirm that of Grasselly.

Now the inheritance of this characteristic has been demonstrated, we plan to carry out new crosses (Table 3 ) that will give 100 per cent self-compatible seedlings $\left(\mathrm{F}_{2}\right)$, by using the most outstanding offspring $\left(\mathrm{F}_{1}\right)$.

\section{Conclusions}

The results obtained are consistent with the assumption of monofactorial control of self-compatibility, the gene concerned, $S_{f}$, being dominant over all selfincompatible alleles of the $S$-gene. They also suggest that Genco and Tuono are heterozygous for $S_{\mathrm{f}}$. 
The seemingly anomalous behaviour of Ferragnès, giving 100 per cent of SC seedlings when used as female parent in crosses with heterozygous selfcompatible cultivars, suggests the presence of a shared self-incompatible allele in both parents.

The obligatory presence of a shared allele of $S_{\mathrm{i}}$, when a heterozygous self-compatible cultivar selfpollinates, also gives rise to families with 100 per cent self-compatible seedlings. The confirmation of this assumption bears out the shared allele theory in the cases mentioned above.

That Genco and Tuono carry the same compatibility alleles $\left(S_{\mathrm{p}} S_{\mathrm{i}}\right)$ is confirmed by the fact that when they pollinate each other, the results are identical to those obtained when they are self-pollinated.

Finally, the possibility of using the most outstanding offspring to carry out new crosses which will secure 100 per cent of self-compatible seedlings, has been proposed.

\section{References}

CYPRUS Agricultural RESEARCH instutute 1973. Annual report for 1972. Nicosia.

CRANE, M. B. AND BROWN, A. J. 1937. Incompatibility and sterility in the sweet cherry (Prunus avium L.). J. Pom. Hort. Sci., 15, 86-116.

CRANE, M. B. AND LAWRENCE, w. J. C. 1947. The Genetics of the Garden Plants. Macmillan, London.

EGEA, J., GARCiA, J. E., EGEA, L. AND Berenguer, T. 1988. Degré de compatibilité intervarietale en amandier. Étude differentielle au moyen de fluorescence. 7 Colloque GREMPA. Reus, June 1987, pp. 165-174.

FELIPE, A. J. 1977. Stadi fenologici del mandorlo. 3 Colloque GREMPA . Bari, October 1977, pp. 101-103.

GARCIA, J. E. 1978. Biología floral de variedades cultivadas de Prunus amygdalus, Batsch. PhD Thesis. Centro de Edafología y Biología Aplicada del Segura, (CSIC), Murcia, Spain.

GARCIA, J. E., EgEA, L., EgEA, J. AND BERENGUER, T. 1985. Programme d'amélioration de l'amandier au CEBAS de Murcie. Options Méditerr. Serie Études, 1, 7-8.

GODINI, A. 1977. Contributo alla conoscenza delle cultivar di mandorlo della Puglia: (2) Un cuadrienio di ricerche sull'autocompatibilitá. 3 Colloque GREMPA. Bari, October 1977, pp. 203-214.

GODINI, A. 1979. Ipotesi sulla comparsa dell'autocompatibilitá nel mandorlo. Sci. Téc. Agr., 19, 3-10.
GRASSELlY, CH. 1985. Avancement du programme 'autocompatibilité chez l'amandier'. Options Méditerr. Serie Études, 1, 39-41.

GRASSELly, CH., CROSSA RAYNAUd, P., OLIVER, G. AND GALl, H. 1981. Transmission du caractère d'autocompatibilité chez l'amandier (Amygdalus communis). Options Méditerr. Serie Études, 1, 71-75.

GRASSElly, CH. AND OLIVIER, G. 1976. Mise en évidence de quelques types autocompatibles parmi les cultivars d'amandier de la population des Pouilles. Ann. Amélior. Plant, 26, 107-113.

GRASSELly, CH. AND OLIVIER, G. 1988. Phénomènes d'inbreeding dans les descendances issues d'autofecondation chez l'amandier. 7 Colloque GREMPA. Reus, June 1987. pp, 73-78.

JAOUANI, A. 1973. Étude de l'autocompatibilité de la variété 'Mazzetto'. Rapp. Activ. Lab. Arbo. Fruit. INRA (Tunez), pp. 20.

JRAIDI, B. AND NEFZI, A. 1988. Transmission de l'autocompatibilité chez l'amandier. 7 Colloque GREMPA. Reus, June 1987, pp. 47-57.

LEWIS, D. AND CROWEL, K. 1954. The induction of self-fertility in tree fruits. J. Hortic. Sci., 29, 220-225.

LINSKENS, H. F. AND ESSER, K. 1957. Uber eine spezifische anfärbung der pollenschläuche im griffel und die zahl der kallosepfropfen nach selbstung und fremdung. Naturwissenschaften, 44, 16-12.

MARTIN, F. W. 1959. Staining and observing pollen tubes in the style by means of fluorescence. Stain Technol., 34, $125-128$.

REINA, A., GIORGIO, V. AND GODINI, A. 1986. Cultivar autocompatibili nella popolazione pugliese de mandorlo. Frutticoltura, 12, 61-63.

SOCIAS I COMPANY, R. 1984. A genetic approach to the transmission of the compatibility in almond. Options Méditerr. Serie Études, 2, 123-128.

SOCIAS I COMPANY, R. 1989. Estado actual y perspectivas de la mejora genética del almendro para la autocompatibilidad. Infecion. Téc. Econ. Agra., 85, 3-22.

SOCIAS I COMPANY, R. AND FELIPE, A. J. 1977. Ereditabilitá dell'autocompatibilitá nel mandorlo. 3 Colloque GREMPA. Bari, October 1977, pp. 221-223.

SOCIAS I COMPANY, R. AND FELIPE, A. J. 1988. Self-compatibility in almond: transmission and recent advances in breeding. Acta Hortic., 224, 307-317.

STAZIONE AGRARIA SPERIMENTALE DI BARI 1951. Relazione sull'attività del triennio 1948-1950, pp. 1-72.

STAZIONE AGRARIA SPERIMENTALE DI BARI 1957. Relazione sull'attività della Stazione nel decennio 1947-1956, pp. $1-161$. 